\title{
Pancreatic metastases originating from uterine leiomyosarcoma: a case report
}

\author{
Simona Olimpia Dima ${ }^{1 \dagger}$, Nicolae Bacalbasa ${ }^{2 \dagger}$, Mihai Adrian Eftimie ${ }^{1}$ and Irinel Popescu ${ }^{1 *}$
}

\begin{abstract}
In this report, we describe the case of a 67-year-old woman with metastatic pancreatic uterine leiomyosarcoma. She underwent a total hysterectomy and adnexectomy in December 2009. The resected uterine specimen was characterized as a leiomyosarcoma. The patient was free of disease until November 2010, when three pulmonary tumoral lesions detected by follow-up chest computed tomography were diagnosed as metastatic lesions. Wedge resections and enucleoresection of the pulmonary tumoral nodules were performed, and the patient received adjuvant chemotherapy. Ten months after the lung resection, an abdominal examination showed two tumoral masses in the pancreas and no extrapancreatic recurrence. In April 2014, a pylorus-preserving pancreaticoduodenectomy was performed. To date, the patient is alive, without any evidence of recurrence, and she has received chemotherapy. Surgery can be considered in cases in which the pancreas is a unique metastatic site or even in cases with resectable oligometastases.
\end{abstract}

Keywords: Pancreatic metastases, Resectable oligometastases, Uterine leiomyosarcoma

\section{Background}

Uterine leiomyosarcoma (LMS) is a rare malignancy with high metastatic potential. Patients with metastatic or recurrent disease have a poor prognosis with limited treatment options. The 5-year survival rates are $53 \%$ in patients with stage I uterine LMS and $8 \%$ in those with stages II through IV disease [1,2]. The most common sites of metastatic LMS are the lung, the peritoneal cavity and the liver [3,4]. A case of pancreatic metastasis from a uterine LMS is rare [5,6]. Ogura et al. identified, in a literature review, 25 cases of LMS metastases to the pancreas, of which 7 cases were from a primary uterine tumor [7]. In this report, we describe a case of a patient with metastatic pancreatic uterine LMS.

\section{Case presentation}

A 67-year-old womanwith a medical history of hypertension and hyperthyroidism presented to our hospital with postmenopausal vaginal bleeding in 2009. A transvaginal ultrasound showed a tumoral mass in the uterine wall that was initially interpreted as a leiomyoma. In

\footnotetext{
*Correspondence: irinel.popescu220@gmail.com

${ }^{\dagger}$ Equal contributors

1"Dan Setlacec" Center of General Surgery and Liver Transplantation, Fundeni Clinical Institute, Soseaua Fundeni 258, Bucharest 022328, Romania

Full list of author information is available at the end of the article
}

December 2009, she underwent a total hysterectomy and bilateral adnexectomy. The surgically resected uterine specimen was characterized as a LMS (pT1c) with immunohistochemistry results positive for smooth muscle actin (SMA) and desmin and a Ki-67 level of 30\%. No adjuvant radiochemotherapy was administered, but a follow-up examination every 6 months was recommended. The patient was free of disease until November 2010, when three pulmonary tumoral lesions $7 \mathrm{~mm}, 8.34-\mathrm{mm}$ and $5 \mathrm{~mm}$ in size, respectively, in the inferior lobe of the left lung were detected by follow-up chest computed tomography (CT) (Figure 1). To clarify the differential diagnosis between a primary lung tumor and metastatic disease, the multidisciplinary panel decided to perform surgery.

Wedge resections and enucleoresection of the lung tumoral nodules were performed in November 2011. The histopathological examination of the resected lung specimen revealed the presence of spindle-shaped cells with a high mitotic count. The immunohistochemistry was positive for SMA and desmin and negative for CD10, MNF116 antibody and estrogen receptor/progesterone receptor, and her Ki-67 level was 30\%, thus clarifying the diagnosis of a metastatic LMS. Postoperatively, the patient received chemotherapy consisting of one cycle of 


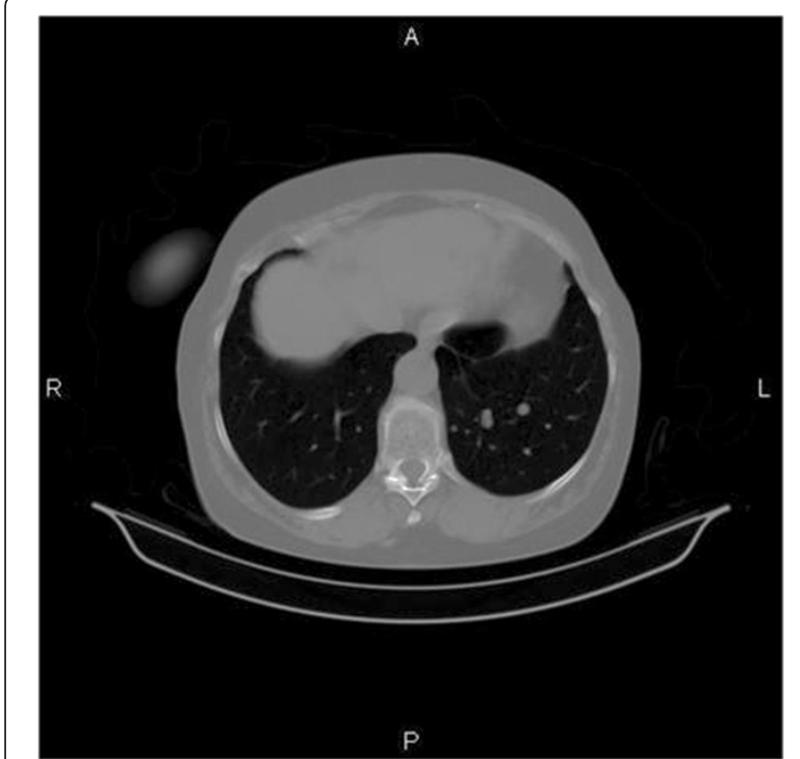

Figure 1 Chest computed tomography. The pulmonary nodular tumor invasion.

Epirubicin $150 \mathrm{mg}+$ Cisplatin (CDDP)100 $\mathrm{mg}$ and gemcitabine + vinorelbine (six cycles).

The regular follow-up CT scan obtained in July 2011, 10 months after the lung resection, showed two tumoral masses in the pancreas at the junction of the head and body. Whole-body positron emission tomography (PET) performed in September 2011 (Figure 2) showed heterogeneous enhancement at the level of the pancreatic head with metabolic activity, indicating malignant potential of

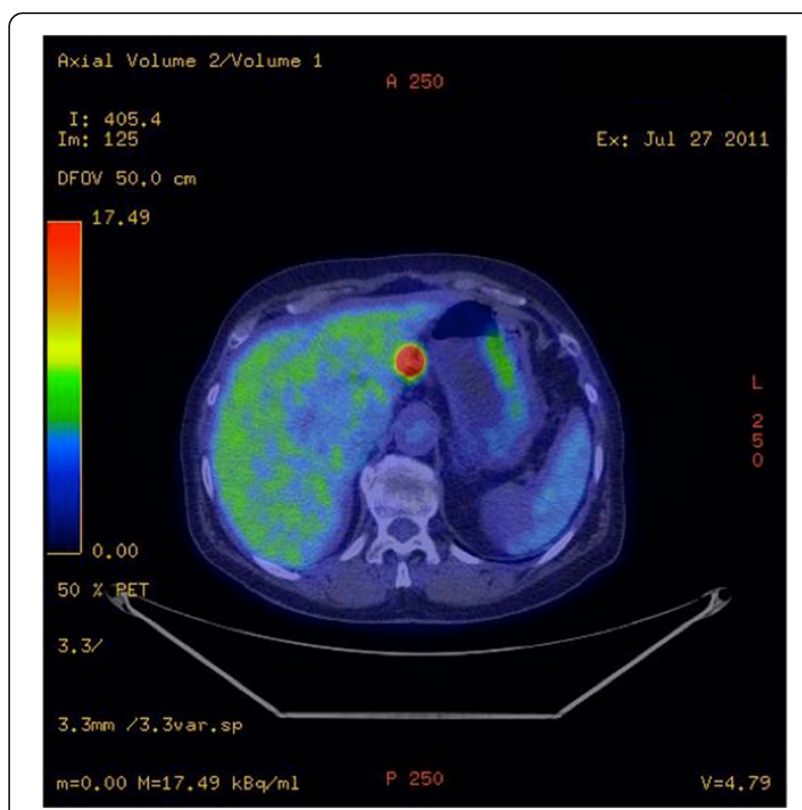

Figure 2 Positron emission tomography/computed tomography revealed a mass in the pancreatic head with metabolic activity. the lesions, and no evidence of extrapancreatic metastatic lesions.

The oncological context and the multiplicity of the pancreatic lesions following the metastatic pulmonary disseminations oriented the diagnosis towards pancreatic metastases rather than a primary pancreatic tumor. In terms of the biohumoral markers, the carcinoembryonic antigen (CEA) and carbohydrate antigen (CA 19-9) levels were as follows: $2 \mathrm{ng} / \mathrm{ml}$; CA 19-9, $14 \mathrm{U} / \mathrm{ml}$; however, an above upper limit level of chromogranin A could have allowed a differential diagnosis of a primary pancreatic neuroendocrine tumor.

Because of the previous episode of lung metastases, which suggested systemic dissemination, probably with other occult metastatic lesions, the oncological panel decided on systemic chemotherapy. In September 2011, the patient was switched to a combination of gemcitabine $\left(1,800 \mathrm{mg} / \mathrm{m}^{2}\right)$ plus dacarbazine $\left(500 \mathrm{mg} / \mathrm{m}^{2}\right)$. PET/ CT performed in December 2013 showed a slight increase in the size of the pancreatic lesions and no signs of extrapancreatic recurrence. Because acquired chemoresistance was suspected and because the disease was apparently limited to the pancreas, a decision was made to perform a pancreatic resection. In April 2014, a pylorus-preserving pancreaticoduodenectomy was performed (Figure 3). Microscopically, the surgically resected pancreatic specimen showed features similar to those of the uterine LMS. The immunohistochemical studies showed that the neoplastic cells were positive for SMA and desmin and negative for chromogranin and synaptophysin.

The patient's postoperative course was uneventful, and she was discharged on the 12th postoperative day. To date, the patient is alive, without any evidence of recurrence.

\section{Discussion}

Pancreatic isolated metastases are a rare condition, most frequently originating from primary renal cell carcinomas

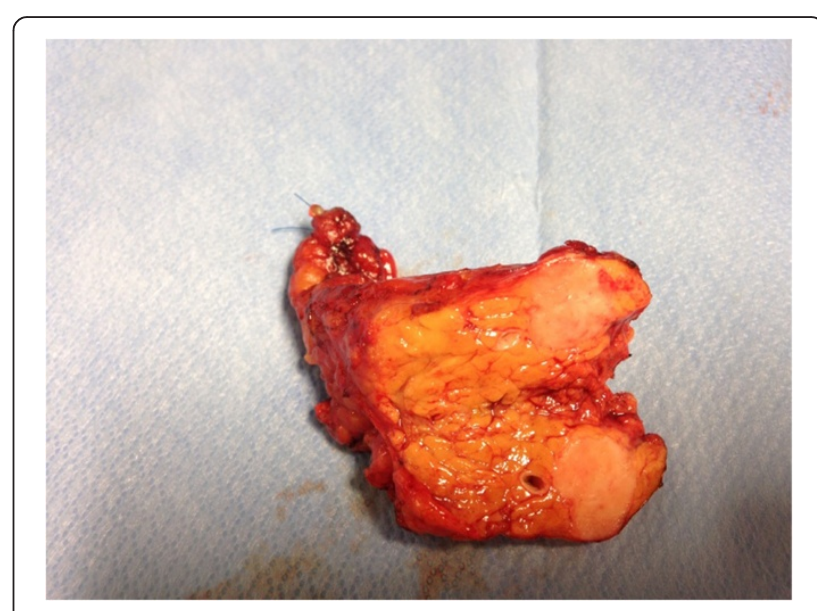

Figure 3 Surgical specimen from the pancreaticoduodenectomy. 
Table 1 First recurrence of pancreatic tumor

\begin{tabular}{|c|c|c|c|c|c|c|c|c|c|c|}
\hline Authors & Primary therapy & $\begin{array}{l}\text { Adjuvant } \\
\text { therapy }\end{array}$ & $\begin{array}{l}\text { Time to } 1 \mathrm{st} \\
\text { recurrence } \\
\text { (months)/site } \\
\text { of recurrence }\end{array}$ & $\begin{array}{l}\text { Neoadjuvant } \\
\text { treatment }\end{array}$ & $\begin{array}{l}\text { Surgical } \\
\text { treatment of } \\
1 \text { st recurrence }\end{array}$ & $\begin{array}{l}\text { Adjuvant treatment } \\
\text { after } 1 \text { st recurrence } \\
\text { surgery }\end{array}$ & $\begin{array}{l}\text { Time to second } \\
\text { recurrence } \\
\text { (months)/site } \\
\text { of recurrence }\end{array}$ & $\begin{array}{l}\text { Surgical } \\
\text { treatment of } \\
\text { second } \\
\text { recurrence }\end{array}$ & $\begin{array}{l}\text { Postsurgical } \\
\text { adjuvant } \\
\text { therapy }\end{array}$ & $\begin{array}{l}\text { Survival after } \\
\text { pancreatic } \\
\text { surgery }\end{array}$ \\
\hline Falconi et al. [10] & $\begin{array}{l}\mathrm{TH}+\mathrm{BO} \\
\text { (February 1996) }\end{array}$ & NA & $\begin{array}{l}52 \text { (June 2000) } \\
\text { Pancreas }\end{array}$ & $C i+C y+D o$ & $\begin{array}{l}\text { PPD + LR } \\
\text { (March 2001) }\end{array}$ & No & $\begin{array}{l}12 \text { mo } \\
\text { (March 2002) liver }\end{array}$ & TACE & $\begin{array}{l}\text { Pelvic recurrence } \\
\text { RT and I+D + } \\
\text { Da + M (2004) }\end{array}$ & Alive, 56 mo \\
\hline Ozturk et al. [3] & $\begin{array}{l}\mathrm{H}+\mathrm{LO}+\text { Om } \\
\text { (December 2008) }\end{array}$ & $\begin{array}{l}\text { RTh + Do } \\
\text { and Ci }\end{array}$ & $\begin{array}{l}\text { Pancreas } \\
\text { (May 2013) }\end{array}$ & No & $\begin{array}{l}\text { DP + Spl } \\
\text { (HP-leiomyosarcoma) }\end{array}$ & No & No & No & No & Alive, 6 mo \\
\hline Kao et al. [16] & $\mathrm{TH}+\mathrm{BO}$ & NA & $\begin{array}{l}\text { Lung, } \\
\text { pancreas }\end{array}$ & NA & PD & NA & NA & NA & NA & NA \\
\hline Skagias et al. [15] & 2010 & & Pancreas & no & Partial pancreatectomy & & & & & \\
\hline
\end{tabular}


Table 2 Second recurrence of pancreatic tumor

\begin{tabular}{|c|c|c|c|c|c|c|c|c|c|c|}
\hline Authors & $\begin{array}{l}\text { Primary } \\
\text { therapy }\end{array}$ & $\begin{array}{l}\text { Adjuvant } \\
\text { therapy }\end{array}$ & $\begin{array}{l}\text { Time to } 1 \text { st } \\
\text { recurrence } \\
\text { (months)/site } \\
\text { of recurrence }\end{array}$ & $\begin{array}{l}\text { Neoadjuvant } \\
\text { treatment }\end{array}$ & $\begin{array}{l}\text { Surgical } \\
\text { treatment of } \\
1 \text { st recurrence }\end{array}$ & $\begin{array}{l}\text { Adjuvant } \\
\text { treatment after } \\
\text { 1st recurrence } \\
\text { surgery }\end{array}$ & $\begin{array}{l}\text { Time to second } \\
\text { recurrence } \\
\text { (mo)/site of } \\
\text { recurrence }\end{array}$ & $\begin{array}{l}\text { Surgical } \\
\text { treatment } \\
\text { of second } \\
\text { recurrence }\end{array}$ & $\begin{array}{l}\text { Postsurgical } \\
\text { adjuvant therapy }\end{array}$ & $\begin{array}{l}\text { Survival after } \\
\text { pancreatic } \\
\text { surgery }\end{array}$ \\
\hline Iwamoto I et al. [5] & $\begin{array}{l}\mathrm{TH}+\mathrm{BO} \\
\text { (February 2002) }\end{array}$ & RTh + 18 Gy & 12 Lung & No & $\begin{array}{l}\text { Video-assisted } \\
\text { thoracic surgery }\end{array}$ & $\begin{array}{l}\text { Chemotherapy } \\
\mathrm{Ep}+\mathrm{Cy}+\mathrm{Ca}\end{array}$ & $\begin{array}{l}\text { Pancreas (12 } \\
\text { mo) }\end{array}$ & $\mathrm{DP}+\mathrm{Spl}$ & No & Alive, $8 \mathrm{mo}$ \\
\hline Alonso GJ et al. [6] & July 2005 & $\mathrm{RTh}+\mathrm{Br}$ & 5 Lung & Chemotherapy & $\begin{array}{l}\text { Upper left } \\
\text { lobectomy } \\
\text { (7 mo) }\end{array}$ & $\begin{array}{l}\text { Chemotherapy } \\
\text { (NA) }\end{array}$ & Pancreas (8 mo) & $\begin{array}{l}\text { Segmental } \\
\text { pancreatectomy }\end{array}$ & $\begin{array}{l}\text { Recurrence in the } \\
\text { lung and liver; } \\
\text { bevacizumab } \\
(18 \mathrm{mo})\end{array}$ & Alive, $18 \mathrm{mo}$ \\
\hline Hernandez S et al. [14] & $\begin{array}{l}\mathrm{H}+\mathrm{BO} \\
\text { (November } 2003\end{array}$ & RTh & $\begin{array}{l}\text { Lung (2 mo, } \\
\text { February 2004) }\end{array}$ & $\begin{array}{l}\text { Ifosfamide + } \\
\text { A + Mesna }\end{array}$ & $\begin{array}{l}\text { Segmentary } \\
\text { resection }\end{array}$ & Gemcitabine & $\begin{array}{l}\text { Pancreas (47 mo, } \\
\text { January } 2008\end{array}$ & PD (April 2008) & NA & Alive, $67 \mathrm{mo}$ \\
\hline Clemente G et al. [13] & $\mathrm{H}+\mathrm{BO}$ & NA & 144 & NA & PD & NA & NA & NA & NA & NA \\
\hline $\begin{array}{l}\text { Chatzipantelis P et al. } \\
\text { [17] }\end{array}$ & NA & NA & $\begin{array}{l}\text { Left axillary and } \\
\text { right femoral } \\
\text { metastases }\end{array}$ & NA & NA & & $\begin{array}{l}\text { Pancreas (FNA) } \\
\text { positive for } \\
\text { malignancy } \\
(120 \mathrm{mo})\end{array}$ & $\mathrm{DP}+\mathrm{Spl}$ & & \\
\hline
\end{tabular}


[8]. The incidence of metastatic pancreatic tumors has been reported to be $3 \%$ to $11 \%[9,10]$. A uterine sarcoma metastasized to the pancreas is an extremely rare condition which ensures that the decision regarding treatment is difficult and nonstandardized. The decision is determined by an attending multidisciplinary oncology team.

Differentiation of a primary pancreatic adenocarcinoma or of neuroendocrine tumors from a metastatic pancreatic tumor is required to perform neoadjuvant therapy. CT and magnetic resonance imaging are used for the evaluation of the pancreatic mass. Highly vascularized tumors are more likely to be metastases than primary tumors, which are hypovascular. The difficulty lies in distinguishing the tumors, on the basis of imaging, between pancreatic metastatic tumors and pancreatic neuroendocrine tumors, which are hypervascular as well [11]. Percutaneous fine-needle aspiration (FNA) is helpful in the preoperative differential diagnosis between a primary and metastatic pancreatic tumor. However, the published data have shown a difference between the immunohistochemical findings on the endoscopic ultrasound-guided FNA (EUS-FNA) and the final immunohistochemistry results from the resected specimen.

The survival benefit of the resection of pancreatic metastases has been demonstrated. Reddy and Wolfgang [12], in a systemic review of the literature, evaluated 243 patients who had undergone radical pancreatic resection for metastatic disease and concluded that the effectiveness of pancreatic resection for a metastatic tumor is dependent on the tumor biology of the primary cancer. In other case reports [3,5,6,10,13-17], authors have described good long-term survival following an aggressive surgical approach, indicating a possible benefit of surgery in the metastatic setting for selected cases (Tables 1 and 2).

In our patient, the long interval between the detection of the pancreatic mass and its resection (33 months), during which time the patient was managed by subsequent cycles of chemotherapy, provided the reason for the oncologist's and surgeon's reluctance to resort to surgery, questioning its benefit in a secondary metastatic setting. A wait-and-see attitude regarding chemotherapy was preferred, and the decision to perform surgery was taken as a result of suspected chemoresistance after a long interval of stable disease.

\section{Conclusions}

Surgery can be considered in the pancreas as a unique metastatic site or even in cases with resectable oligometastases. We hypothesize that a long disease-free interval following resection of a primary tumor might be an indicator of a more indolent tumor biology or chemoresponsiveness, and thus we question the possibility of the surgical benefit for these select cases.

\section{Consent}

Written informed consent was obtained from the patient for publication of this Case report. A copy of the written consent is available for review by the Editor-in-Chief of this journal.

\section{Abbreviations \\ CT: Computed tomography; FNA: Fine-needle aspiration; LMS: Leiomyosarcoma; PET: Positron emission tomography.}

\section{Competing interests}

The authors declare that they have no competing interests.

\section{Authors' contributions}

IP performed the operation, SOD performed the literature search, had responsibility for patient care, SO D and NB wrote the paper, MAE collected radiological materials, obtained patient consent, IP, SOD and NB proofread the paper. All authors read and approved the final manuscript.

\section{Acknowledgements}

This manuscript has been supported by National research grant PNII-PT-PCCA 90/2012 and by the Romanian - EEA Research Programme EEA-JRP-RO-NO-2013$1-0363$.

\section{Author details}

"Dan Setlacec" Center of General Surgery and Liver Transplantation, Fundeni Clinical Institute, Soseaua Fundeni 258, Bucharest 022328, Romania. ${ }^{2 " C a r o l}$ Davila" University of Medicine and Pharmacy, Bulevardul Eroii Sanitari 8, Bucharest 050474, Romania.

Received: 23 July 2014 Accepted: 5 December 2014

Published: 30 December 2014

\section{References}

1. Salazar OM, Bonfiglio TA, Patten SF, Keller BE, Feldstein M, Dunne ME, Rudolph J: Uterine sarcomas: natural history, treatment and prognosis. Cancer 1978, 42:1152-1160.

2. Salazar OM, Dunne ME: The role of radiation therapy in the management of uterine sarcomas. Int J Radiat Oncol Biol Phys 1980, 6:899-902.

3. Ozturk S, Unver M, Ozturk BK, Bozbıyık O, Erol V, Kebabcı E, Olmez M, Zalluhoglu N, Bayol U: Isolated metastasis of uterine leiomyosarcoma to the pancreas: report of a case and review of the literature. Int J Surg Case Rep 2014, 5:350-353.

4. Rose PG, Piver MS, Tsukada Y, Lau T: Patterns of metastasis in uterine sarcoma: an autopsy study. Cancer 1989, 63:935-938.

5. Iwamoto I, Fujino T, Higashi Y, Tsuji T, Nakamura N, Komokata T, Douchi T: Metastasis of uterine leiomyosarcoma to the pancreas. J Obstet Gynaecol Res 2005, 31:531-534.

6. Alonso Gómez J, Arjona Sánchez A, Martínez Cecilia D, Díaz Nieto R, Roldán de la Rúa J, Valverde Martínez A, Lizárraga Febres E, Padillo Ruiz J, Rufián Peña S: Uterine leiomyosarcoma metastasis to the pancreas: report of a case and review of the literature. J Gastrointest Cancer 2012, 43:361-363.

7. Ogura T, Masuda D, Kurisu Y, Miyamoto Y, Hayashi M, Imoto A, Takii M, Takeuchi T, Inoue T, Tokioka S, Uchiyama K, Umegaki E, Higuchi K: Multiple metastatic leiomyosarcoma of the pancreas: a first case report and review of the literature. Intern Med 2013, 52:561-566.

8. Sweeney JT, Crabtree DK, Yassin R, Somogyi L: Metastatic uterine leiomyosarcoma involving the pancreas diagnosed by EUS with fine-needle aspiration. Gastrointest Endosc 2002, 56:596-597.

9. Adsay NV, Andea A, Basturk O, Kilinc N, Nassar H, Cheng JD: Secondary tumors of the pancreas: an analysis of a surgical and autopsy database and review of the literature. Virchows Arch 2004, 444:527-535.

10. Falconi M, Crippa S, Sargenti M, Capelli P, Pederzoli P: Pancreatic metastasis from leiomyosarcoma of the broad ligament of the uterus. Lancet Oncol 2006, 7:94-95.

11. Z'graggen K, Fernandez-del Castillo C, Rattner DW, Sigala H, Warshaw AL: Metastases to the pancreas and their surgical extirpation. Arch Surg 1998, 133:413-419. 
12. Reddy S, Wolfgang CL: The role of surgery in the management of isolated metastases to the pancreas. Lancet Oncol 2009, 10:287-293.

13. Clemente G, Giordano M, De Rose AM, Nuzzo G: Image of the month: metastasis from leiomyosarcoma in the head of the pancreas. Arch Surg 2010, 145:793-794.

14. Hernández S, Martín-Fernández J, Lasa I, Busteros I, García-Moreno F: Pancreaticoduodenectomy for metastasis of uterine leiomyosarcoma to the pancreas. Clin Transl Oncol 2010, 12:643-645.

15. Skagias L, loulia E, Politi E: Isolated pancreatic metastasis of uterine leiomyosarcoma diagnosed by fine needle aspiration biopsy. Acta Cytol 2010, 54:239-240.

16. Kao YH, Saad U, Tan AE, Magsombol BM, Padhy AK: Fluorine-18fluorodeoxyglucose PET/CT for the evaluation of suspected recurrent uterine leiomyosarcomas. Acta Radiol 2011, 52:463-466.

17. Chatzipantelis P, Karvouni E, Fragoulidis GP, Voros D, Pafiti A: Clinicopathologic features of two rare cases of mesenchymal metastatic tumors in the pancreas: review of the literature. Pancreas 2006, 33:301-303.

doi:10.1186/1477-7819-12-405

Cite this article as: Dima et al.: Pancreatic metastases originating from uterine leiomyosarcoma: a case report. World Journal of Surgical Oncology 2014 12:405

\section{Submit your next manuscript to BioMed Central and take full advantage of:}

- Convenient online submission

- Thorough peer review

- No space constraints or color figure charges

- Immediate publication on acceptance

- Inclusion in PubMed, CAS, Scopus and Google Scholar

- Research which is freely available for redistribution 